\title{
FIBRIN PROMOTION AND LYSIS IN ARTHRITIC JOINTS
}

\author{
BY \\ MARION I. BARNHART*, JEANNE M. RIDDLE, G. B. BLUHM, \\ AND \\ CLOTILDE QUINTANA
}

Wayne State University School of Medicine, Department of Physiology and Pharmacology, and Henry Ford Hospital, Department of Pathology and Division of Rheumatology, Detroit, Michigan

The significance of extravascular coagulation and fibrinolysis is poorly understood and little appreciated. A unique opportunity for studying these events is provided in arthritis where the joint fluids may reflect the presence and extent of inflammation. This report on 144 pathological fluids expands our knowledge of the biochemistry of inflammation. Further, it may provide a more instructive base than currently available for comprehending the mechanisms operative in arthritis. Fibrin deposition must be considered seriously as a contributor to permanent joint damage.

Synovial fluid is a complex mixture of substances largely derived from the plasma but also the product and recipient of both cells in the synovial membrane and extravascular leucocytes (Ropes and Bauer, 1953). Protein comprises 1.4 to 5.6 per cent. of the synovial fluid and is mainly known in terms of electrophoretic properties (Decker, McKenzie, McGuckin, and Slocumb, 1959; Schur and Sandson, 1963; Schmid, 1964) except for rheumatoid factor (Krehl, Boisvert, de Forest, and Mucci, 1957) and several enzymes (Ziff, Simson, Scull, Smith, Shatton, and Mainland, 1955; Jacox and Feldmahn, 1955; Smith and Hamerman, 1962). There is little quantitative information on specific proteins. We selected globulins that function in fibrin formation and degradation for measurement as they are constituents of inflammation fluids but are considered absent in synovial fluid (Ropes and Bauer, 1953; Cho and Neuhaus, 1960). When present with cellular products, activation may occur to yield or destroy fibrin (Seegers, 1962; Barnhart, 1963; Purcell and Barnhart, 1963).

The resulting protein profiles chiefly reflected grades of inflammation. However, quantitative differences in the precursors for fibrin were noted when osteo-

*Aided by NIH Research Grant H.E. 03447 from the United States Public Health Service. arthritis (OA), rheumatoid arthritis (RA), and gout (G) were compared. These data support our earlier suggestion that continued fibrin deposition may maintain a vicious circle of inflammation (Riddle, Bluhm, and Barnhart, 1965; Bluhm, Riddle, and Barnhart, 1966). The permanence of joint damage may relate to the efficacy of mechanisms operative in fibrin removal.

\section{Material and Methods}

Patients (90) with joint disease provided 144 synovial fluids. The rheumatoid patients (38 with 72 effusions) met the American Rheumatism Association Criteria for Classical or Definite Rheumatoid Arthritis. Other patients had gout (15 gave 19 fluids), pseudo-gout (3), septic arthritis (2 gave 6 fluids), Reiter's syndrome (2), psoriatic arthritis (5 had 7 effusions), ankylosing spondylitis (4), monarticular arthritis (3), and rheumatoid arthritis with a transient LE-cell phenomenon (3 had 5 effusions). One patient with recurring allergic arthritis had two effusions. Single joint aspirates came from patients with the following conditions: regional ileitis, scleroderma, uraemia, and three undiagnosed. These last 35 joint effusions from 26 patients were not grouped by disease in the illustrations because of insufficient numbers but were simply classed as "miscellaneous $\bigcirc$ inflammations". Degenerative joint disease ( 9 patients $\rightarrow$ with 13 effusions) was chosen to provide examples of so-called "noninflammatory" fluids. Several other patients (Charcot's joint, early systemic lupus erythe- $O$ matosus, and traumatic arthritis) provided joint effusions $N$ (5) with low grades of inflammation or near normal N biochemistry.

The aspirated synovial fluid was immediately anticoagulated with 3.8 per cent. sodium citrate (1 vol plus $9 \stackrel{\circ}{C}$ vols aspirate). The gross appearance was noted as was $\mathbb{D}$ the presence of visible particulates. Cell counts were $\stackrel{?}{?}$ routine. Cells and other sedimenting material were $\underset{T}{T}$ removed by centrifugation. Biochemical assays were $O$ performed on the particulate-free synovial fluid either immediately or after storage at $-20^{\circ} \mathrm{C}$. In 57 per cent. of the patients, plasma was acquired at the time of joint aspiration. 


\section{Proteins involved in Blood Coagulation}

Fibrinogen was evaluated on the basis of heat coagulability at $56^{\circ} \mathrm{C}$. (Stirland, 1956) and on clottability with thrombin (Ware, Guest, and Seegers, 1949), after addition of epsilon-aminocaproic acid $(0.05 \mathrm{M})$ to inhibit fibrinolysis. Prothrombin was determined by two-stage procedure (Ware and Seegers, 1949). For small amounts of prothrombin (1 to $20 \mathrm{U}$ ) reference was made to a special activity curve prepared from diluted highly purified prothrombin of known unitage.

Antithrombin was evaluated qualitatively by the prolongation of the clotting time of a control plasma. For quantitative assay of antithrombin III, chromatographed thrombin (1500 Iowa units) was mixed with synovial fluid and the loss of thrombin was measured (Seegers, Miller, Andrews, and Murphy 1952). Results were expressed as per cent. of thrombin remaining after 2 hrs incubation.

Fibrin related breakdown products, as well as those of fibrinogen, were quantitated by immunological assay to provide a measure of proteolysis. A turbidimetric assay of the antigen-antibody complex was made with a Turner spectrofluorometer and the aid of a highly-specific antibody for fibrinogen (Barnhart, 1967). The antifibrinogen was prepared in rabbits from tannic acid purified human fibrinogen and the specificity was established by immuno-electrophoresis and agar diffusion against purified human proteins, plasma, and serum according to published methods (Barnhart, Anderson, and Baker, 1962). Synovial fluids were recalcified and thrombin was added to clot out any fibrinogen present. After centrifugation to sediment clottable protein, the supernatant $(0 \cdot 1 \mathrm{ml}$. of serial dilutions $1 / 10$ to $1 / 320)$ was added to physiological saline $(4.8 \mathrm{ml})$. and mixed with univalent antifibrinogen $(0.1 \mathrm{ml}$.). The mixture was incubated at $37^{\circ} \mathrm{C}$. for 1 hour to permit complexing of antifibrinogen with the nonclottable breakdown products of fibrin and fibrinogen. Turbidity readings were converted to mg. fibrinogen-related material (FRM) by reference to a standard curve prepared from the interaction of known amounts of purified fibrinogen with the antibody under similar conditions. Normal serum contained about $\mathbf{0 . 3} \mathrm{mg}$. nonclottable fibrinogenrelated molecules per $\mathrm{ml}$.

\section{Electrophoretic Distribution of Proteins}

Cellulose acetate electrophoresis was run in Spinco cells (standard and microzone). Where viscosity of the synovial fluid was a problem, another sample was incubated with hyaluronidase and dialysed before electrophoresis. Immuno-electrophoresis was done with polyvalent anti-human serum (Hyland) and monovalent antisera specific for each of the following highly purified proteins; prothrombin, fibrinogen, rheumatoid factor (IgM), gamma globulin (IgG), profibrinolysin, and albumin.

\section{Miscellaneous Procedures}

Total protein was measured by the biuret test (Robinson and Hogden, 1940). The differential rheumatoid factor titre (DRAT) was determined by a modified sheep cell agglutination test (Rose, Ragan, Pearce, and Lipman, 1948). Profibrinolysin quantitation employed a standard fibrin clot (Guest, 1954).

\section{Results}

\section{General Patterns of Protein Distribution}

The total protein of the joint effusions varied from 7 to $58 \mathrm{mg} . / \mathrm{ml}$. (Fig. 1). In a few cases the synovial fluid protein was in the range of concentration considered normal for plasma total protein (50 to $80 \mathrm{mg} . / \mathrm{ml}$.). Normal synovial fiuid has 10 to $25 \mathrm{mg}$. protein/ml. (Ropes and Bauer, 1953). Our lowest values ( 7 to $24 \mathrm{mg}$.) were seen in effusions from patients with early systemic lupus erythematosus, traumatic arthritis, and Charcot's joint. As other measurements for these three fluids were low, we assigned the classification of near normal biochemistry (Fig. 1). Fluids from OA varied from 15.5 to $34 \mathrm{mg} . / \mathrm{ml}$. (average $26 \pm 4.7 \mathrm{mg} . / \mathrm{ml}$.). The 72 fluids from RA had protein values from 15 to $53 \mathrm{mg} . / \mathrm{ml}$. (average $37 \pm 8 \mathrm{mg} . / \mathrm{ml}$.) synovial fluid. Protein from miscellaneous inflammatory joints varied from 8 to $58 \mathrm{mg} . / \mathrm{ml}$. (average $39 \pm 10 \mathrm{mg} . / \mathrm{ml}$.)

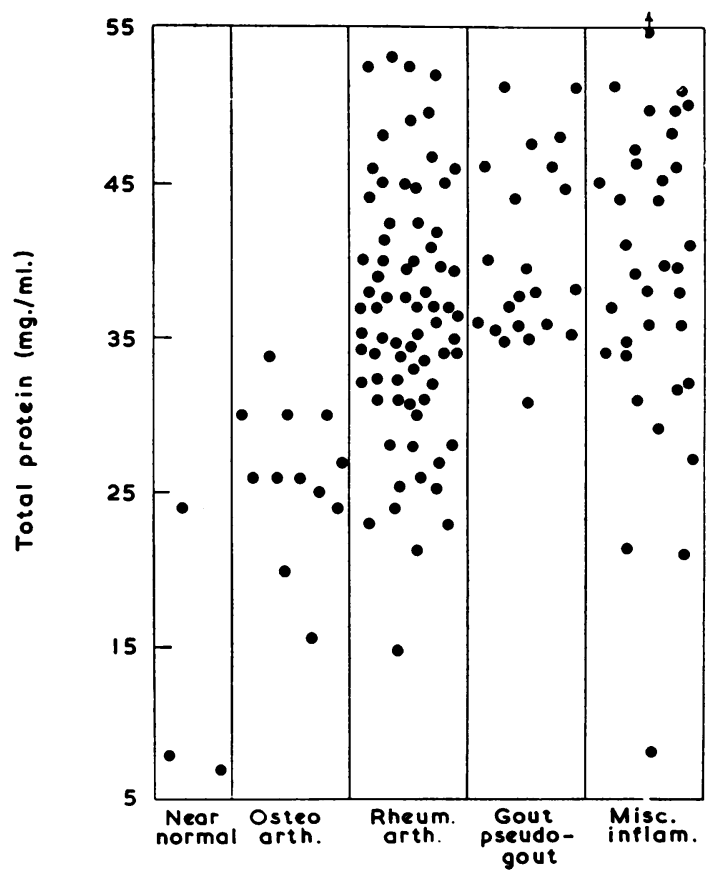

Fig. 1.-Distribution of total protein in synovial fluids from cases of arthritic disease

The highest value ( $24 \mathrm{mg}$.) in the near normal group came from a Charcot's joint. The lowest value $(8 \mathrm{mg}$.) in the miscellaneous exudates was from a patient with uraemia.

Cellulose acetate electrophoresis of the synovial fluids gave patterns similar to those for plasma or serum. All of the usual protein groups were 
present with globulin especially increased. In comparison to normal synovial fluid, reported to have an albumin/globulin (A/G) ratio of 2 , our fluids with four exception out of 102 had lower $A / G$ values (Fig. 2). Sixteen fluids ranged between $1 \cdot 2$ to $1 \cdot 6$. Of these six were from OA and one from Charcot's joint. With $\mathrm{A} / \mathrm{G}$ ratios of $1 \cdot 1$ or less were 81 per cent. without OA represented. The $a_{2}$ globulin was increased relative to $a_{1}$ globulin to give $a_{1} / a_{2}$ ratios with an average of 0.64 in comparison to the normal near 1 according to Binette and Schmid (1965). The $\beta$ globulins were increased considerably and ranged from $2 \cdot 2$ to $16 \mathrm{mg}$. $/ \mathrm{ml}$. to reach in some cases a concentration equivalent to that for normal serum or plasma. The only synovial exudates with lower $\beta$ globulin were from the systemic lupus erythematosus, traumatic arthritis, and two cases of OA. The Charcot's joint measured $2.6 \mathrm{mg}$. $/ \mathrm{ml}$. All the other inflammatory fluids exceeded by two to eight times the values calculated for normal joints ( $1 \cdot 6$ to $2 \cdot 2 \mathrm{mg} . / \mathrm{ml}$.).

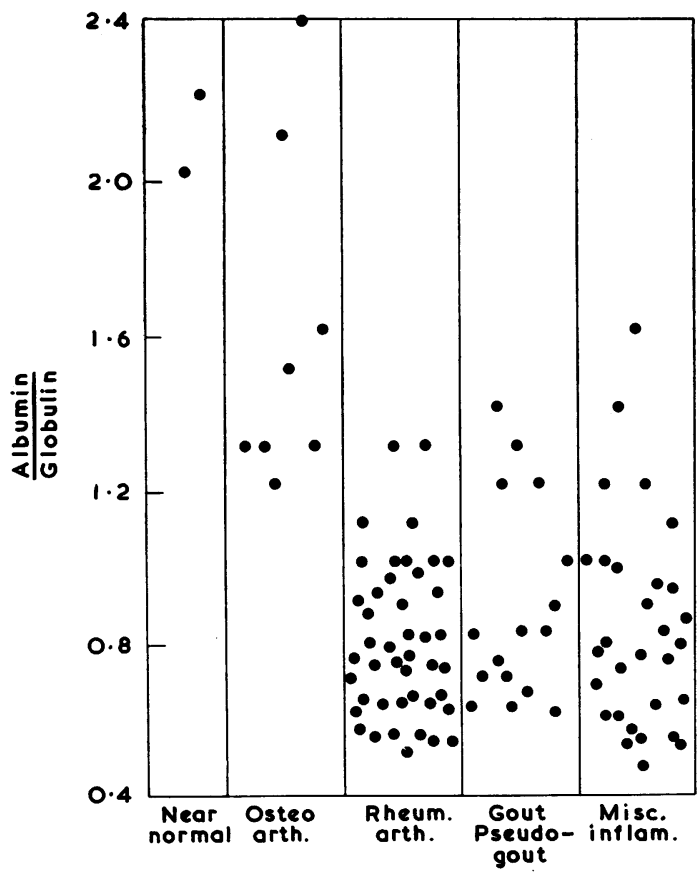

Fig. 2.-Comparison of albumin and globulin content of synovial fluids obtained from several types of joint disease.

Immuno-electrophoresis permitted identification of several of the globulins in these inflammatory synovial fluids. A number of arcs occurred in the $a_{2}, a_{1}$, and albumin areas (Fig. 3A) when reacted with polyvalent antiserum. The position of the precipitins was not positive identification of the reactants as proteolysis may alter the mobilities of exposed proteins. Each of our immunological reagents was proven to be without cross-reactions with any other plasma protein. Albumin-related molecules were identified with anti-albumin. One of the $a_{2}$ globulins was prothrombin or immunological relatives because a precipitin arc was formed when synovial fluid was reacted with the specific antiprothrombin (Fig. 3B). The $\beta$ globulins contained molecules that were either fibrinogen or breakdown products of fibrinogen and fibrin because reaction occurred in the region with antifibrinogen (Fig. 3B). Profibrinolysin or fibrinolysin-related molecules also

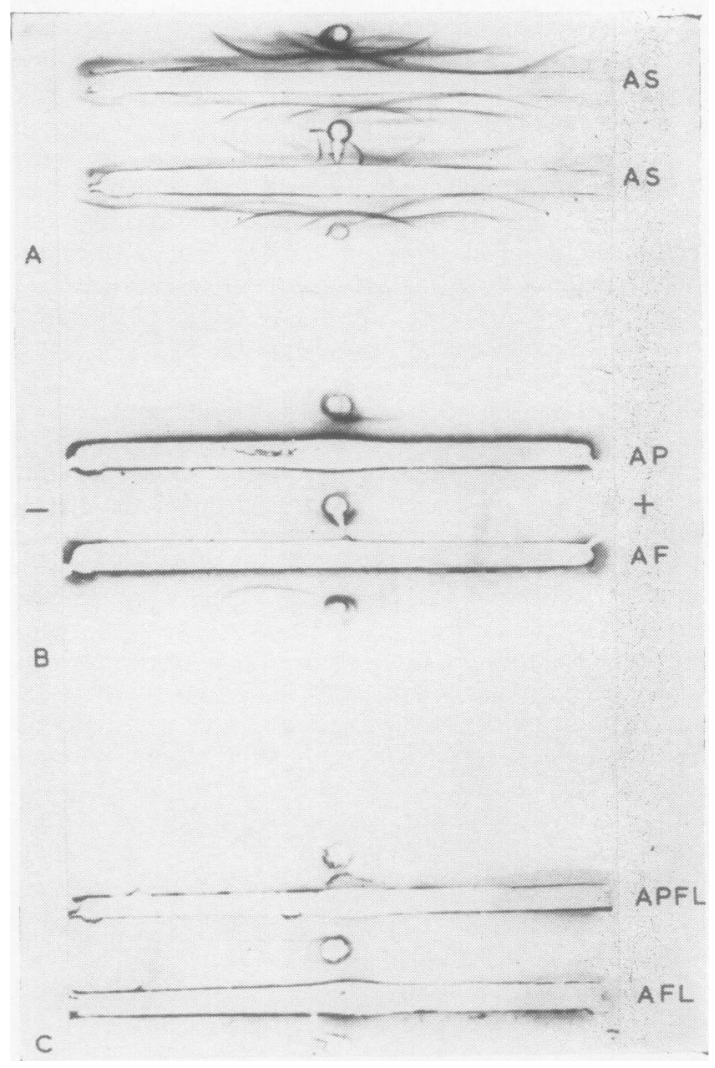

Fig. 3.-Immuno-electrophoretic patterns representative of the local protein biochemistry of joint disease.

A. Numerous proteins exist in synovial fluids. Many have A. Numerous proteins exist in synovial fluids. Many have tin bands formed when reacted with anti whole serum (AS).

B. Prothrombin was usually identified in the synovial exudates. The short $a_{2}$ band in the upper pattern was formed by reaction with antiprothrombin (AP) Fibrinogen or immunologically-related molecules were found when antifibrinogen (AF) was used. These precipitin arcs can be seen faintly in the middle pattern and more prominently in the lower pattern in the $\beta_{2}$ region. This position suggests that the fibrinogen has been altered or the arc identifies a product from local proteolysis.

C. Profibrinolysin or fibrinolysin was identified by reaction with C. Profibrinolysin or fibrinolysin was identified by reaction with
antiprofibrinolysin (APFL) and antifibrinolysin (AFL). Note the faint precipitin lines in the $\beta$ region of the centre section. 
were present in the $\beta$ globulin fraction since a precipitin band formed when antiprofibrinolysin was used for immunological identification (Fig. 3C). Some of the synovial fluids from RA patients exhibited a $\beta_{2}$ precipitin arc against an anti-IgG to form a long precipitin in the $a, \beta$, and $\gamma$ areas.

\section{Presence of Blood Coagulation Proteins}

Normal synovial fluid has been reported as being essentially free of proteins important in clot formation (Ropes and Bauer, 1953; Cho and Neuhaus, 1960). During inflammation with increased vascular permeability, blood clotting proteins might be expected to appear. With quantitative methods of assay, both prothrombin and fibrinogen were found in the majority of synovial exudates examined. Since special care was taken with the aspiration technique to avoid contamination of the synovial fluid with blood, it is likely that the presence of prothrombin and fibrinogen reflected increased membrane permeability coincident with disease.

Prothrombin.-This was measurable in significant amounts in 86 per cent. of the joint effusions (Fig.

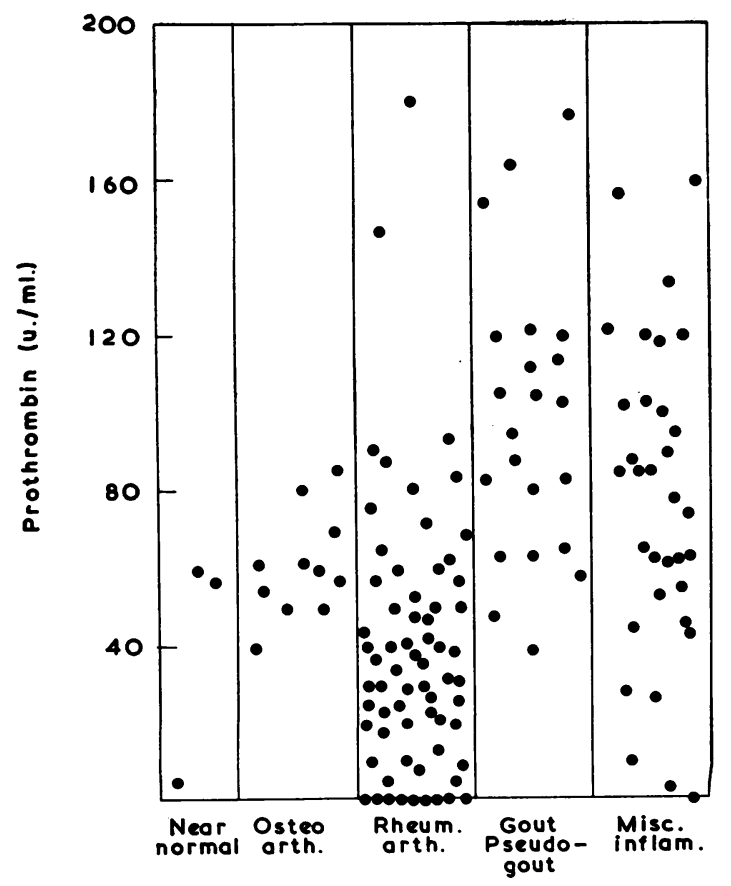

Fig. 4.-Prothrombin distribution in pathological synovial fluids. For comparison, normal plasma contains about $200 \mathrm{U} / \mathrm{ml}$ with the current reagents. Note the relatively low prothrombin values in RA. Also three of the five miscellaneous exudates below $40 \mathrm{U} / \mathrm{ml}$ came from patients with RA and transient L.E.-cell phenomena; the other two were from uraemic and allergic arthritic patients.
4). Values ranged down from $180 \mathrm{U} / \mathrm{ml}$ (mean $58 \mathrm{U} / \mathrm{ml}$.) when all patients were considered. The highest prothrombins were found in nonrheumatoid patients excepting OA. Of 54 effusions in this category, 76 per cent. were above $60 \mathrm{U} / \mathrm{ml}$. Considering only the gout and pseudo-gout series of 22 fluids, 86 per cent. exceeded $60 \mathrm{U} / \mathrm{ml}$. The OA series averaged $60 \mathrm{U} / \mathrm{ml}$. Only 19 per cent. of the RA series had more than $60 \mathrm{U}$ prothrombin $/ \mathrm{ml}$. The majority of RA fluids fell below $40 \mathrm{U} / \mathrm{ml}$., and 22 per cent. of these had $10 \mathrm{U} / \mathrm{ml}$. or less.

Comparison was made of individual plasma and synovial fluid prothrombins from 46 patients with 73 joint effusions. The synovial fluid/plasma ratios were calculated as indexes of extravascular movement of prothrombin. Two near normal fluids averaged $0 \cdot 14$. The five fluids from $O A$ averaged $0 \cdot 33$. The seventeen gout fluids averaged $0 \cdot 46$. Four miscellaneous effusions averaged $0 \cdot 65$. The 45 RA fluids gave an average of $\mathbf{0} \cdot \mathbf{2 0}$. More than half of the RA patients had plasma prothrombin levels near 200 $\mathrm{U} / \mathrm{ml}$. but their synovial fluid prothrombins varied from 0 to $91 \mathrm{U} / \mathrm{ml}$. The eight nonrheumatoid fluids ranged from 48 to $160 \mathrm{U} / \mathrm{ml}$. synovial fluid with plasma prothrombins near $200 \mathrm{U} / \mathrm{ml}$. Another eight patients had multiple joint effusions aspirated on the same date; of these six showed significantly different prothrombin concentrations, as well as other biochemical variations between their joints. Such results suggest that, in the rheumatoid patient, the movement of prothrombin across the synovial membrane is restricted or that the frequently encountered low prothrombin is the result of local prothrombin activation and consumption in the joint.

To examine the first possibility that selective membrane permeability limited the extravascular movement of prothrombin, the synovial fluid/plasma values for albumin and profibrinolysin were compared with the prothrombin ratios (Table I, overleaf). It was apparent that molecular size was not the limiting factor in RA. Both albumin of similar molecular weight to prothrombin and profibrinolysin with a larger molecular weight showed greater extravascular movement than did prothrombin in $\mathbf{7 8}$ per cent. of the RA fluids. The nonrheumatoid fluids, except the near normals, had ratios of similar magnitude for all three proteins.

Further evidence that local activation was an important determinant of prothrombin concentration was provided by the gross fibrin found in RA effusions. Comparison was made between the presence of fibrin and the prothrombin concentration in $55 \mathrm{RA}$ effusions. Of the forty fluids with 
TABLE I

COMPARISON OF PLASMA/SYNOVIAL FLUID RATIOS FOR SEVERAL PLASMA PROTEINS

\begin{tabular}{|c|c|c|c|c|c|}
\hline \multirow{2}{*}{ Condition } & \multirow{2}{*}{ Patient } & \multicolumn{4}{|c|}{ Synovial Fluid/Plasma Values } \\
\hline & & Prothrombin & Albumin & Profibrinolysin & Total protein \\
\hline Near Normal & Bar & $0 \cdot 25$ & & 0.03 & $0 \cdot 18$ \\
\hline Osteo-Arthritis & $\begin{array}{l}\text { Caw-1 } \\
\text { Caw-2 } \\
\text { Ham }\end{array}$ & $\begin{array}{l}0 \cdot 33 \\
0 \cdot 36 \\
0 \cdot 38\end{array}$ & & $\begin{array}{l}0.35 \\
0.47 \\
0.52\end{array}$ & $\begin{array}{l}0.43 \\
0.45 \\
0.41\end{array}$ \\
\hline Rheumatoid Arthritis & $\begin{array}{l}\text { Bie } \\
\text { Bor-1 } \\
\text { Bor-2 } \\
\text { Bur-1 } \\
\text { Bur-2 } \\
\text { Bur-3 } \\
\text { Bur-4 } \\
\text { Bur-5 } \\
\text { Ege } \\
\text { Pur } \\
\text { Re } \\
\text { Reh } \\
\text { Rog } \\
\text { Sta }\end{array}$ & $\begin{array}{l}0 \cdot 43 \\
0 \cdot 07 \\
0 \cdot 21 \\
0 \cdot 35 \\
0 \cdot 10 \\
0 \cdot 04 \\
0 \cdot 19 \\
0 \cdot 16 \\
0 \cdot 16 \\
0 \\
0 \cdot 38 \\
0 \cdot 22 \\
0 \cdot 19 \\
0 \cdot 65\end{array}$ & $\begin{array}{l}0.39 \\
0.70 \\
0.59 \\
0.73 \\
0.91 \\
0.68 \\
0.79 \\
0.71 \\
0.61 \\
0.75 \\
0.74\end{array}$ & $\begin{array}{l}0 \cdot 86 \\
0 \cdot 40 \\
0 \cdot 38 \\
0 \cdot 56 \\
0 \cdot 57 \\
0 \cdot 57 \\
0 \cdot 64 \\
0 \cdot 67 \\
0 \cdot 24 \\
0 \cdot 44 \\
0 \cdot 76 \\
0 \cdot 23 \\
0 \cdot 51\end{array}$ & $\begin{array}{l}0 \cdot 36 \\
0 \cdot 66 \\
0 \cdot 66 \\
0 \cdot 61 \\
0 \cdot 74 \\
0 \cdot 78 \\
0 \cdot 74 \\
0 \cdot 78 \\
0 \cdot 59 \\
0 \cdot 60 \\
0 \cdot 48 \\
0 \cdot 70 \\
0 \cdot 73 \\
0 \cdot 77\end{array}$ \\
\hline Miscellaneous Inflammation & $\begin{array}{l}\text { Har } \\
\text { Lov } \\
\text { McD } \\
\text { Osb }\end{array}$ & $\begin{array}{l}0.48 \\
0.78 \\
0.69 \\
0.65\end{array}$ & $\begin{array}{l}0 \cdot 61 \\
0 \cdot 61 \\
0 \cdot 74 \\
0 \cdot 52\end{array}$ & $\begin{array}{l}0.62 \\
0.54 \\
0.72\end{array}$ & $\begin{array}{l}0.61 \\
0.70 \\
0.67 \\
0.50\end{array}$ \\
\hline
\end{tabular}

visible fibrin, the prothrombin was less than 60 $\mathrm{U} / \mathrm{ml}$. in 90 per cent., and 63 per cent. of these had less than $30 \mathrm{U} / \mathrm{ml}$. 29 aspirates had from 4 to 38 per cent. of their fluid volume as fibrin, which had formed in vivo and 92 per cent. exhibited less than $60 \mathrm{U} / \mathrm{ml}$. In contrast, fifteen RA fluids did not exhibit fibrin and had an average prothrombin of $62 \mathrm{U} / \mathrm{ml}$., 13 per cent. having less than $30 \mathrm{U} / \mathrm{ml}$. It seems reasonable to conclude that, in the severely inflamed rheumatoid joint, the observed fibrin was probably preceded by the activation of prothrombin to form thrombin. Such activation and consumption of prothrombin could account for the unusually low prothrombin concentration found in the joints of rheumatoid arthritics.

Prothrombin is an $\alpha_{2}$ globulin and was identified by immuno-electrophoresis in many of the synovial fluids (Fig. 3B). In general, the $a_{2}$ electrophoretic protein group was increased in our exudates to reach in some cases to $16 \mathrm{mg}$. $/ \mathrm{ml}$. From the quantitative data on the biological activity of prothrombin, it is apparent that the entire increase of $a_{2}$ globulin cannot be accounted for in terms of prothrombin. It may be a valid assumption that $2000 \mathrm{U}$ human prothrombin is equivalent to $1 \mathrm{mg}$. prothrombin, for this is an established relationship for bovine prothrombin (Seegers, 1962). Application of these figures to the highest synovial fluid prothrombin
$(180 \mathrm{U} / \mathrm{ml}$.) accounts for only $0.09 \mathrm{mg}$. as prothrombin, although this patient had $12 \mathrm{mg}$. $a_{2}$ globulin. Clearly some proteins besides prothrombin were present to account for the increased $a_{2}$ fraction.

Antithrombin.-Although prothrombin was found in many of the synovial exudates, the active enzyme, thrombin, was not demonstrable in these fluids. It was conceivable that antithrombin, a natural plasma inhibitor of thrombin, might become a constituent of synovial fluid as might antithrombin of tissue origin.

Two different methods established that antithrombins were present in many of the synovial fluids. Qualitative information was gained for eleven RA fluids that contained different amounts of prothrombin. Nine of these effectively neutralized thrombin as it formed in the test system. Antithrombin III was determined in another twenty synovial fluids and four plasmas (Table II, opposite). Antithrombin was measurable in 80 per cent. of the synovial fluids and neutralized from 7 to 36 per cent. of the added thrombin. The higher values were similar to normal plasma. In two patients (Arm and Lov) the synovial fluid value was lower than that of the matched plasma. The magnitude of the antithrombin was not obviously related to the prothrombin level nor to the type of joint disease. More likely the antithrombin level is another manifestation of the degree of inflammation. 
TABLE II

ANTITHROMBIN ACTIVITY IN SYNOVIAL FLUIDS

\begin{tabular}{|c|c|c|c|c|}
\hline & Material & Patient & $\begin{array}{l}\text { Prothrombin } \\
\text { (U/ml.) }\end{array}$ & $\begin{array}{l}\text { Antithrombin III } \\
\text { per cent. Thrombin Remaining }\end{array}$ \\
\hline \multirow{3}{*}{ Synovial Fluid } & Rheumatoid Arthritis & $\begin{array}{l}\text { All } \\
\text { Bur } \\
\text { Joh-1 } \\
\text { Joh-2 } \\
\text { Mat } \\
\text { Mck } \\
\text { Pra } \\
\text { Sta }\end{array}$ & $\begin{array}{r}8 \\
20 \\
71 \\
18 \\
2 \\
4 \\
0 \\
128\end{array}$ & $\begin{array}{r}26 \\
31 \\
7 \\
0 \\
15 \\
24 \\
0 \\
20\end{array}$ \\
\hline & Gout & $\begin{array}{l}\text { Arm } \\
\text { As } \\
\text { Hub } \\
\text { Tuk } \\
\text { Voe }\end{array}$ & $\begin{array}{r}66 \\
90 \\
96 \\
84 \\
124\end{array}$ & $\begin{array}{r}16 \\
7 \\
17 \\
36 \\
31\end{array}$ \\
\hline & Miscellaneous Inflammation & $\begin{array}{l}\text { Cow } \\
\text { Lov } \\
\text { McD } \\
\text { Ver-1 } \\
\text { Ver-2 } \\
\text { Wil } \\
\text { Tho }\end{array}$ & $\begin{array}{r}82 \\
120 \\
96 \\
50 \\
68 \\
8 \\
44\end{array}$ & $\begin{array}{r}27 \\
15 \\
0 \\
10 \\
0 \\
25 \\
17\end{array}$ \\
\hline Plasma & & $\begin{array}{l}\text { Arm } \\
\text { Lov } \\
\text { Normal-1 } \\
\text { Normal-2 }\end{array}$ & $\begin{array}{l}182 \\
204 \\
170 \\
230\end{array}$ & $\begin{array}{l}58 \\
36 \\
30 \\
44\end{array}$ \\
\hline
\end{tabular}

Fibrinogen and Fibrin.--Most synovial fluids did not show any fibrinogen on the basis of heat precipitability. Fibrinogen, clottable by thrombin, was detected in 89 per cent. of 144 synovial fluids (Fig. 5). The three near normal fluids averaged $0.03 \mathrm{mg} . / \mathrm{ml}$. The twelve $\mathrm{OA}$ fluids averaged 0.18 $\mathrm{mg} . / \mathrm{ml}$. In RA, 71 fluids had a mean of 0.39 $0.46 \mathrm{mg}$. $/ \mathrm{ml}$. while 61 per cent. exceeded $0.18 \mathrm{mg}$./ $\mathrm{ml}$. The gout and pseudo-gout series (22) had a mean of $0.56 \pm 0.62 \mathrm{mg} . / \mathrm{ml}$. and 67 per cent. exceeded $0.18 \mathrm{mg} . / \mathrm{ml}$. Miscellaneous inflammations (36) had 56 per cent. exceeding $0.18 \mathrm{mg} . / \mathrm{ml}$. (mean $0.39 \pm 0.44 \mathrm{mg} . / \mathrm{ml}$.).

The question of whether or not increased fibrinogen transudation and its utilization in the joint to form fibrin had provoked a compensatory hepatic synthesis and release was considered. Results from 74 plasmas obtained from the patients at the time of their joint aspirations were compatible with a stimulated state of fibrinogen metabolism. For comparison, 56 plasmas from normal healthy individuals were found to contain $1.74 \pm 0.71 \mathrm{mg}$./ $\mathrm{ml}$. In contrast, 10 per cent. of the plasmas from subjects with joint disease were within 1 standard deviation (SD) of this normal value. The closest correspondence to the normal plasma fibrinogen occurred in OA (5) with 80 per cent. falling within 2 SD. In the miscellaneous series some 36 per cent. were within 2 SD. Results from patients with RA or gout were generally high and plasma fibrinogen varied between $3 \cdot 17$ and $7 \cdot 11 \mathrm{mg} . / \mathrm{ml}$. The RA series (39) had 80 per cent. exceeding 2 SD. The C

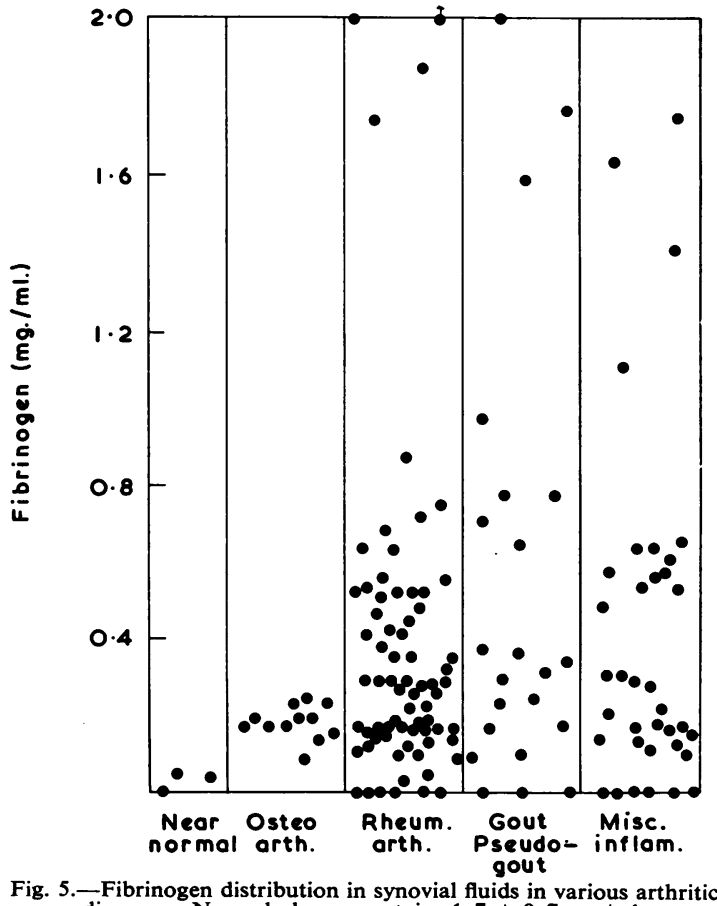

Fig. 5.- Fibrinogen distribution in synovial fluids in various ar
diseases. Normal plasma contains $1.7 \pm 0.7 \mathrm{mg} . / \mathrm{ml}$.

gout series (17) had 88 per cent. with plasma fibrinogen greater than 2 SD of normal.

Fibrin, that had formed in vivo, was visible to the eye in many of the anticoagulated effusions as strands or masses. Identification was made on the basis of immunological reactivity with fluorescent 
antifibrinogen (Bluhm, and others, 1966). In 74 per cent. of the RA fluids (68), the fibrin mass accounted for 1 to 38 per cent. of the total volume aspirated. The gout and pseudo-gout series (22) had 32 per cent. with small fibrin masses which seldom composed 2 per cent. of the total fluid volume. The miscellaneous inflammations (31) had 29 per cent. exhibiting fibrin but all were from RA patients with a transient L.E.-cell phenomenon. In contrast, the OA (12) and near normals (3) did not have visible fibrin. Only 4 per cent. of the group of 136 were totally negative for both fibrin and fibrinogen.

Molecules related to Fibrin and Fibrinogen.-The $\beta$ globulin fraction was increased in most inflammatory fluids to three to six times the normal. This elevation also occurred in patients without evidence of RA. Immuno-electrophoresis of most effusions showed molecules in the $\beta$ globulin region that reacted with specific antifibrinogen (Fig. 3B). Although clottable fibrinogen frequently was present (Fig. 5) some other nonclottable immunological relatives of fibrinogen also were present (Fig. 6).

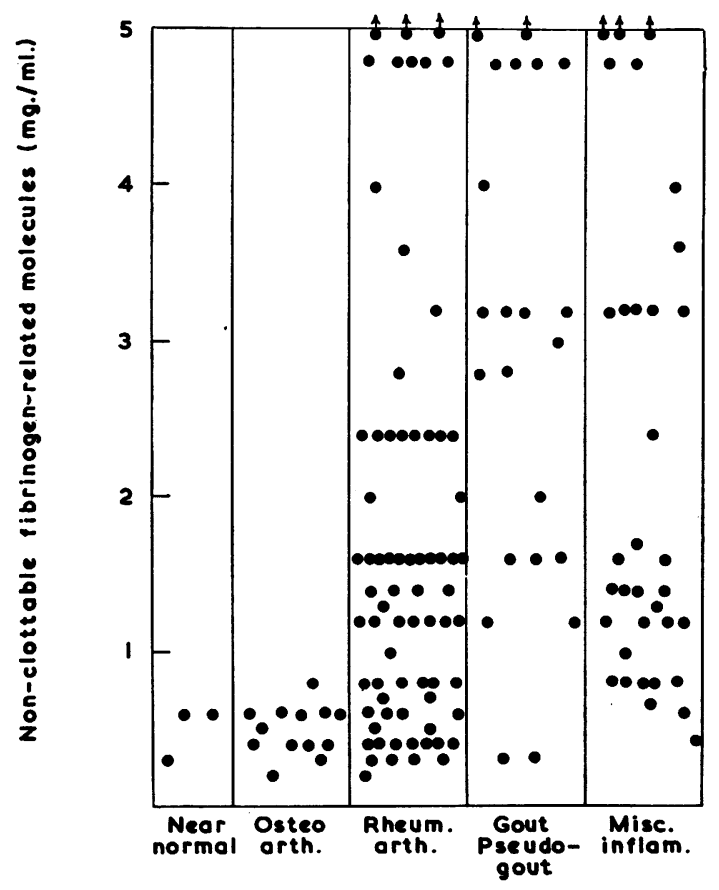

Fig. 6.-Evidence for in vivo proteolysis of fibrin or fibrinogen. Distribution of nonclottable fibrinogen-related molecules as determined by quantitative precipitin reaction with univalent antifibrino-

It was possible to gain some quantitative information on proteolysis products of fibrinogen and fibrin by immunological assay after removal of clottable fibrinogen. Values for nonclottable fibrinogen relatives varied from $0 \cdot 2$ to as much as $6 \cdot 4$ $\mathrm{mg} . / \mathrm{ml}$. (Fig. 6). The least evidence of proteolysis of fibrin occurred in near normal (3) and OA fluids (13), which averaged $0.5 \mathrm{mg} . / \mathrm{ml}$. The RA series (72) had a mean of $1 \cdot 7 \pm 1.4 \mathrm{mg} . / \mathrm{ml}$, with 64 per cent. outside the $\mathrm{OA}$ range. Gout and pseudo-gout fluids (22) had a mean of $2.9 \pm 1.5 \mathrm{mg}$. $/ \mathrm{ml}$., with 90 per cent. exceeding the OA group. Miscellaneous effusions (34) had a mean of $2 \cdot 3 \pm 1 \cdot 8 \mathrm{mg} . / \mathrm{ml}$. Serum from 56 normals ranged from 0.2 to 0.6 $\mathrm{mg} . / \mathrm{ml}$. (average 0.3). Serum values for the patients seldom exceeded the normal even when the synovial fluid nonclottable fibrinogen-related molecules were high.

Further support for the view that nonclottable fibrinogen-related molecules were products of local digestion of fibrin and/or fibrinogen came from examination of the synovial fluid/serum ratios for the soluble molecules (Tables III and IV, opposite).

In contrast to other protein transudations with ratios under 1 (Table I), the ratios for nonclottable fibrinogen-related molecules reached as high as 16:1. These ratios did not correlate with the fibrinogen ratios which were low. Comparison of values for breakdown products in the gout and rheumatoid series suggests that considerably more fibrin proteolysis was going on in the gouty than in the RA joint. Some 85 per cent. of the gout fluids had synovial fluid/serum ratios greater than 4:1 (Table III); only 61 per cent. of the RA fluids exceeded 4:1 (Table IV).

\section{Amount of Synovial Fluid Protein related to} Fibrinogen

An astonishing amount of the $\beta$ globulin was fibrinogen-related material (Table $\mathrm{V}$, overleaf). All the joint fluids exceeded the normal serum quantity of 3 per cent. $\beta$ globulin which existed as nonclottable fibrinogen-related molecules. Most exudates were raised above the normal plasma value of 17 per cent. $\beta$ globulin accountable mainly as fibrinogen. For example, 67 per cent. of the RA fluids (42), 87 per cent. of the gout fluids (16), and 80 per cent. of the miscellaneous exudates $(30)$ exceeded the normal plasma value.

In terms of total protein, the fibrinogen-related molecules of normal plasma comprised 4 per cent. Of the OA fluids only 16 per cent. exceeded the normal. In RA 48 per cent. exceeded the normal. Gout had 81 per cent. and the miscellaneous fluids had 78 per cent. with more than 4 per cent. of their total protein as fibrinogen-related molecules. 
TABLE III

BLOOD/SYNOVIAL FLUID RATIOS OF FIBRINOGEN-RELATED MOLECULES IN VARIOUS CONDITIONS

\begin{tabular}{|c|c|c|c|}
\hline Condition & Patient & $\begin{array}{c}\text { Nonclottable Fibrinogen- } \\
\text { Related Molecules } \\
\text { (Synovial Fluid/Serum) }\end{array}$ & $\begin{array}{l}\text { Clottable Fibrinogen } \\
\text { (Synovial Fluid/Plasma) }\end{array}$ \\
\hline Near Normal & & 0.75 & 0 \\
\hline Osteo-Arthritis & $\begin{array}{l}\text { Caw-1 } \\
\text { Caw-2 } \\
\text { Ham } \\
\text { Spi } \\
\text { Ten }\end{array}$ & $\begin{array}{l}0 \cdot 86 \\
0 \cdot 86 \\
2 \cdot 0 \\
1 \cdot 5 \\
1 \cdot 3\end{array}$ & $\begin{array}{l}0.06 \\
0.06 \\
0.09 \\
0.08 \\
0.07\end{array}$ \\
\hline Charcot's Joint & & $1 \cdot 5$ & 0.02 \\
\hline Traumatic Arthritis & & $2 \cdot 0$ & 0.01 \\
\hline Psoriatic Arthritis & $\begin{array}{l}\text { Osb-1 } \\
\text { Osb-2 }\end{array}$ & $\begin{array}{l}7 \cdot 9 \\
1 \cdot 3\end{array}$ & $\begin{array}{l}0 \\
0.21\end{array}$ \\
\hline Gout & $\begin{array}{l}\text { Arm-1 } \\
\text { Arm-2 } \\
\text { Arm-3 } \\
\text { Arm-4 } \\
\text { As-1 } \\
\text { As-2 } \\
\text { Bog } \\
\text { Bro } \\
\text { Hub } \\
\text { Kuc } \\
\text { Mac } \\
\text { Voe-1 } \\
\text { Voe-2 }\end{array}$ & $\begin{array}{r}7 \cdot 0 \\
16 \cdot 0 \\
8 \cdot 0 \\
16 \cdot 0 \\
12 \cdot 0 \\
14 \cdot 0 \\
13 \cdot 0 \\
5 \cdot 3 \\
7 \cdot 5 \\
0 \cdot 4 \\
6 \cdot 4 \\
4 \cdot 0 \\
1 \cdot 5\end{array}$ & $\begin{array}{l}0 \cdot 15 \\
0 \cdot 04 \\
0 \cdot 02 \\
0 \cdot 06 \\
0 \cdot 33 \\
0 \cdot 29 \\
0 \\
0 \cdot 09 \\
0 \\
0 \cdot 09 \\
0 \cdot 15 \\
0 \cdot 21 \\
0 \cdot 55\end{array}$ \\
\hline Septic Arthritis & $\begin{array}{l}\text { Cow-1 } \\
\text { Cow-2 }\end{array}$ & $\begin{array}{r}8 \cdot 0 \\
16 \cdot 0\end{array}$ & $\begin{array}{l}0.05 \\
0.03\end{array}$ \\
\hline
\end{tabular}

TABLE IV

BLOOD/SYNOVIAL FLUID RATIOS OF FIBRINOGEN-RELATED MOLECULES IN RHEUMATOID ARTHRITIS

\begin{tabular}{|c|c|c|}
\hline Rheumatoid Arthritis & $\begin{array}{c}\text { Nonclottable Fibrinogen } \\
\text { Related Molecules } \\
\text { (Synovial Fluid/Serum) }\end{array}$ & $\begin{array}{c}\text { Clottable Fibrinogen } \\
\text { (Synovial Fluid/Plasma) }\end{array}$ \\
\hline $\begin{array}{l}\text { All-1 } \\
\text { All-2 } \\
\text { All-3 } \\
\text { Bie-1 } \\
\text { Bie-2 } \\
\text { Bor-1 } \\
\text { Bor-2 } \\
\text { Bur-1 } \\
\text { Bur-2 } \\
\text { Bur-3 } \\
\text { Bur-4 } \\
\text { Ege } \\
\text { Hou } \\
\text { Joh-1 } \\
\text { Joh-2 } \\
\text { Lah-1 } \\
\text { Lah-2 } \\
\text { Pur-1 } \\
\text { Pur-2 } \\
\text { Re } \\
\text { Reh-1 } \\
\text { Reh-2 } \\
\text { Reh-3 } \\
\text { Rog } \\
\text { Sch } \\
\text { Sta } \\
\text { Top } \\
\text { Wag }\end{array}$ & $\begin{array}{r}1 \cdot 3 \\
1 \cdot 7 \\
8 \cdot 0 \\
5 \cdot 3 \\
6 \cdot 7 \\
2 \cdot 7 \\
4 \cdot 7 \\
4 \cdot 0 \\
9 \cdot 3 \\
16 \cdot 0 \\
10 \cdot 7 \\
2 \cdot 0 \\
6 \cdot 0 \\
1 \cdot 5 \\
6 \cdot 0 \\
1 \cdot 3 \\
1 \cdot 5 \\
8 \cdot 0 \\
1 \cdot 3 \\
0 \cdot 7 \\
8 \cdot 0 \\
6 \cdot 0 \\
1 \cdot 3 \\
7 \cdot 0 \\
6 \cdot 0 \\
10 \cdot 7 \\
2 \cdot 7 \\
16 \cdot 0\end{array}$ & $\begin{array}{l}0.08 \\
0.20 \\
0.07 \\
0.13 \\
0.01 \\
0.48 \\
0.10 \\
0.14 \\
0.25 \\
0.07 \\
0.09 \\
0.24 \\
0.05 \\
0.03 \\
0.02 \\
0.17 \\
0.05 \\
0.13 \\
0.02 \\
0.13 \\
0.18 \\
0.14 \\
0.04 \\
0.02 \\
0.16 \\
0.18 \\
0.05 \\
0.03\end{array}$ \\
\hline
\end{tabular}


TABle V

AMOUNT OF $\beta$-GLOBULIN AND TOTAL PROTEIN IDENTIFIED AS FRIBRINOGEN OR ITS IMMUNOLOGICAL RELATIVES

\begin{tabular}{|c|c|c|c|c|c|}
\hline \multirow{2}{*}{\multicolumn{2}{|c|}{ Fibrinogen-Related Molecules }} & \multicolumn{4}{|c|}{ Number of Patients } \\
\hline & & $\begin{array}{l}\text { Osteo- } \\
\text { Arthritis }\end{array}$ & $\begin{array}{c}\text { Rheumatoid } \\
\text { Arthritis }\end{array}$ & Gout & $\begin{array}{l}\text { Miscellaneous } \\
\text { Inflammations }\end{array}$ \\
\hline (1) Per cent. $\beta$-Globulin & $\begin{array}{c}6-17 \\
18-34 \\
35-51 \\
52-68 \\
69-85 \\
86-100\end{array}$ & $\begin{array}{l}5 \\
2\end{array}$ & $\begin{array}{r}14 \\
17 \\
7 \\
2 \\
1 \\
1\end{array}$ & $\begin{array}{l}2 \\
1 \\
9 \\
2 \\
1 \\
1\end{array}$ & $\begin{array}{r}6 \\
9 \\
10 \\
3 \\
2\end{array}$ \\
\hline (2) Per cent. Total Protein & $\begin{array}{c}1-4 \\
5-8 \\
9-12 \\
13-16\end{array}$ & $\begin{array}{r}6 \\
22 \\
2 \\
8\end{array}$ & $\begin{array}{r}1 \\
12 \\
2 \\
13\end{array}$ & $\begin{array}{l}5 \\
9 \\
5\end{array}$ & $\begin{array}{l}3 \\
2 \\
4\end{array}$ \\
\hline
\end{tabular}

Correlation of Leucocyte Count with Fibrin Volume

An attempt was made to determine the importance of one or more of the protein constituents in the synovial exudates as chemotactic stimuli for the extravascular leucocytes. The various protein parameters previously described and the DRAT values were compared individually and according to disease classification with the proper leucocyte counts. There was no obvious attraction of more leucocytes by the presence of albumin, prothrombin, profibrinolysin, fibrinogen, nonclottable fibrinogen relatives, or the molecules eliciting the DRAT reaction. A positive correlation was obtained between the fibrin volume and the leucocyte numbers (Fig. 7). A measurable fibrin volume occurred only in the RA series. Of the 66 specimens studied, eighteen did not have visible fibrin in their anticoagulated effusions and 72 per cent. of these had leucocyte counts under $10,000 / \mathrm{mm}^{3}$. In contrast, the other 48 specimens showed fibrin, and 46 of these had more than 10,000 leucocytes $/ \mathrm{mm}^{3}$.

\section{Discussion}

Only a few investigators have identified the increased globulins of synovial fluids from joint disease in terms of specific proteins. The a globulin has been related to increased glycoprotein (Decker and others, 1959; Binette and Schmid, 1965) with one $a_{2}$ glycoprotein identified in this study as prothrombin. A large part of the elevated $\beta$ globulin was established as fibrinogen and its immunological relatives. Another $\beta$ globulin, profibrinolysin, was found in many joint fluids and could reflect increased transudation or local release from exudative eosinophils, previously shown to be sites for synthesis and transport (Riddle and Barnhart, $1965)$ to inflamed areas. Some of the $\beta$ globulin elevation included rheumatoid factor (IgM) shown to be present in $\mathrm{RA}$, while the $\gamma$ globulin increase

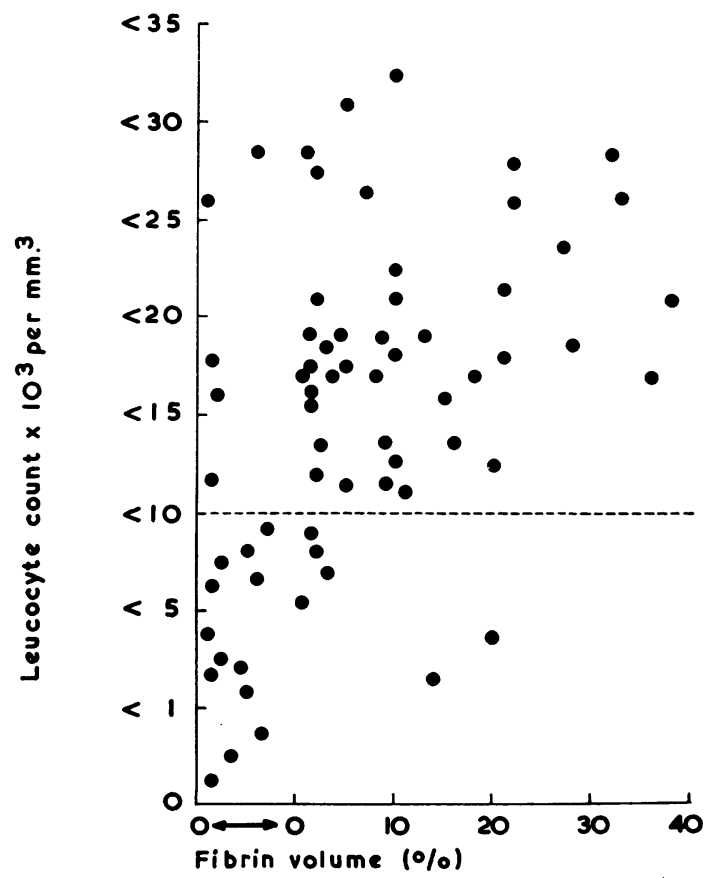

Fig. 7.-Correlation of leucocyte count with fibrin volume in synovial fluids from RA patients. Note that the majority of fluids with more than 10,000 leucocytes $/ \mathrm{mm}^{8}$. had fibrin present to comprise a considerable percentage of the quantity of fluid aspirated. This fibrin was formed in vivo.

may reflect additional antibody or antigen-antibody complexes (Astorga and Bollet, 1965; Hollander, McCarty, Astorga, and Castro-Murillo, 1965).

The biochemical constituents of synovial effusions from the various joint diseases offered few distinctions. However, the biochemical profile may be unique and distinguish inflammation itself. Inflammation is acknowledged as basic defense mechanism for a vast array of agents (Zweifach, Grant and McCluskey, 1965). In our series of patients a 
number of different inflammatory agents elicited the effusions. The influence of these agents on coagulation and lytic proteins that entered the joint may overshadow unique features for specific joint disease.

Our studies illustrate that the essential coagulation proteins, prothrombin and fibrinogen, can gain access to synovial fluid and may approximate plasma levels in joint disease. These proteins can coexist in the absence of activation mechanisms that promote thrombin formation. However, the presence of fibrin in many pathological synovial fluids is evidence of prior activation of coagulation processes. Several agents recognized as valuable for prothrombin activation (Seegers, 1962) have been demonstrated in synovial fluid. Factors V, VIII, and XII were found in pathological fluids (Lewis, Szeto, Martinez, Bayer, Spero, and Rodnan, 1966), and factors XI and XII were reported in normal synovial fluids (Kellermeyer and Breckenridge, 1966). Lipids, possibly released from damaged cells and thought to exert a thromboplastic effect, were elevated in synovial effusions(Kling, 1938; Bole, 1962). Cathepsin has been identified in neutrophils by immunofluorescence (Bluhm and others, 1966) and in synovial fluids from joint disease (Barnhart, Quintana, Lenon, Bluhm, and Riddle, 1967). Cathepsin can activate prothrombin (Purcell and Barnhart, 1963) to yield thrombin and autoprothrombin $\mathrm{C}$, the most powerful procoagulant known (Seegers, 1962). Thus the potential for prothrombin activation and fibrin formation either exists or develops in the synovial fluid with disease. Under appropriate conditions fibrin deposition may be the end-result and should be considered in understanding and treating the joint pathology.

Evidence was gained for different degrees of prothrombin utilization within the joints from various joint diseases. First, the amount of fibrin varied. Secondly, the relatively low prothrombin content of RA effusions was in sharp contrast to signs of membrane damage and increased vascular permeability. Analysis of the data showed that a significant difference $(P<0.01)$ existed between the prothrombin level in RA and all other groups. Most probably prothrombin gained access to the joint and was then activated to various degrees by the procoagulants that became available as a consequence of the specific types of joint disease.

Since fibrinogen and prothrombin may be consumed in the conversion to fibrin, neither provides exact indices of vascular permeability and the extent of membrane damage unless prothrombin activation is limited. Several antithrombin mechan- isms were found in the synovial fluids. Antithrombin III activity was of the same order as that found in plasma and probably originated there. Fibrin itself neutralizes thrombin by adsorption (Seegers, 1962). Finally, the mucopolysaccharide that is so abundant in synovial fluid (Ropes and Bauer, 1953) may have antithrombin activity if it resembles another mucopolysaccharide, heparin, which is a powerful anticoagulant.

Fibrinogen, after gaining access to the synovial fluid, becomes altered even with suppression of the coagulation mechanisms. The disparity in clottability and heat precipitability probably indicate a change in the molecular architecture of the fibrinogen. It may be argued that the viscosity of synovial fluid related to its mucin content prevents the phenomenon of heat precipitation. However, the synovial fluids of our rheumatoid patients were deficient in mucin or contained altered mucin so that their viscosity was similar to that of plasma. It seems more likely that the change in solubility of fibrinogen-related molecules reflected extensive proteolysis in these synovial fluids.

Fibrinolysis produces molecules that have new electrophoretic characteristics in addition to altered solubility and reactivity to thrombin (Seegers, Nieft, and Vandenbelt, 1945; Nussenzweig and Seligmann, 1960). The breakdown products have more charged groups exposed so that they migrate in an electric field somewhat differently from "native" fibrinogen. Synovial fluids of our patients showed evidence of altered fibrinogen or breakdown products according to immuno-electrophoresis. Our findings confirm and extend those of Schur and Sandson (1963), because special precautions were taken to insure that profibrinolysin ( $\beta$ globulin), a contaminant of most purified fibrinogens, was not present in the fibrinogen used to induce antifibrinogen formation. Thus, the $\beta$ reactants in our series could be unequivocally identified as relatives of fibrinogen or profibrinolysin. The major fibrinolytic product was derivative $D$ which has anticoagulant properties.

Further evidence of the fibrinolytic power of the synovial fluids was provided by immunochemical quantitation of molecules that had lost their capacity to clot with thrombin. Such reactants were either altered fibrinogen or breakdown products of fibrin and fibrinogen. In most cases of synovitis with systemic disease, the quantity of these altered molecules exceeded by three to nineteen times the matched blood levels. The near normal and AO fluids ordinarily presented equivalent concentrations 
of altered fibrinogen or breakdown products in synovial fluid and blood. Clearly, a local and extensive proteolysis was a feature of inflammatory joint disease.

Fibrinogen metabolism was obviously unusual in many of our patients with RA and gout. Plasma fibrinogens exceeded the normal value by 2 SD or more in 80 to 90 per cent. of these patients. Takeda and Reeve (1965) observed elevated plasma fibrinogens in their RA patients. Further, with their sensitive radioisotope methods for studying catabolism of fibrinogen, they found extravascular transfer and catabolism increased about twice that of normal humans. Our findings of local utilization in diseased joints suggest a stimulus for increased hepatic synthesis and the frequently elevated plasma fibrinogen.

The attractive power of fibrin or its degradation products in stimulating granulocyte emigration merits consideration in understanding the presenting cellular pattern in various joint inflammations. It was apparent that the leucocyte concentration in many of the joint exudates reported here correlated well with the amount of fibrin found. It may be that the leucocyte emigration was a response to particulate material alone and did not relate to fibrin per se. However, there is good evidence that fibrin or its proteolysis products can attract and maintain the granulocytic phase of inflammation. In experimental inflammatory sites on dogs, autologous fibrin nets provoked emigration of eosinophils and maintained the neutrophil predominance near 100 per cent. of the cell population for from 6 to 14 hours (Riddle and Barnhart, 1964, 1965). A similar chemotactic response to fibrin has been elicited in man utilizing Rebuck's skin window technique (Riddle, Bluhm, Barnhart, and Odle, 1966).

Fibrin or its proteolysis products assume a central role in rheumatic disease. Although the subject of a recent symposium, the possibilities for fibrin have just been defined (Glynn, 1963). At least two fibrin mechanisms may be important alone or operating together:

(i) Fibrin or its immunological relatives perpetuate acute inflammation (Riddle and Barnhart, 1964, 1965). (ii) the autoantigenicity of fibrin has been documented with arthritis one consequence (Glynn, 1963).

Our clinical findings support the view that the severity and duration of the joint inflammations relate to the amount of fibrin deposited. Resolution of such fibrin, either by synovial fluid proteases or by phagocytosis with intracellular digestion by leucocytes, may be essential to terminate the acute inflammatory responses and promote healing.

Analysis of the specific proteins of synovial fluid can provide useful information on the degree of inflammation and exact knowledge of the individual joint. With a base line established, synovianalysis becomes especially valuable in monitoring the individual patients' response to joint disease and treatment. The unexplained remissions encountered in many patients with rheumatoid arthritis complicate the evaluation of drug efficacy. Sequential or serial analysis of selected proteins may provide realistic guides to the host's defences and to the mechanism of action of a drug that truly alters the course of disease. In such a framework, selection of drugs and development of specific drugs for arthritis may become more meaningful.

\section{Summary}

The protein biochemistry of 144 synovial fluids, representative of several types of joint disease, was investigated with special attention to fibrin promoting and lysing proteins. Prothrombin, fibrinogen, antithrombin III, profibrinolysin, and fibrin degradation products were found in the synovial fluids. The quantities of these proteins varied among these inflammatory exudates. Our current interpretation is that these quantitative differences reflect different grades of inflammation rather than define a biochemistry unique for the types of joint disease. Continued and unresolved fibrin deposition may provoke permanent joint damage. Mechanisms for efficient and early removal of fibrin may hasten the healing process.

The capable technical assistance of Mrs. Arlys Vettraino, John Rogers, and Wayne Pitchford was much appreciated. Mrs. Patricia Phillips Levin, of Lafayette Clinic, Computer Laboratory, analysed the data.

\section{REFERENCES}

Astorga, G., and Bollet, A. J. (1965). Arthr. and Rheum., 8, 511 (Diagnostic specificity and possible pathogenetic significance of inclusions in synovial leucocytes). 
Barnhart, M. I. (1963). Thrombos. Diathes. haemorrh. (Stuttg.), 9, Suppl. 2, p. 217 (Interaction of prothrombin and cell systems).

— (1967). In "Blood Clotting Enzymology", ed. W. H. Seegers, chap. 5. Academic Press, New York.

—, Anderson, G. F., and Baker, W. J. (1962). Thrombos. Diathes. haemorrh. (Stuttg.), 8, 21 (Immunochemical studies on proteins important in blood coagulation).

_- Quintana, C., Lenon, H. L., Bluhm, G. B., and Riddle, J. M. (1967). Ann. N.Y. Acad. Sci., in press (Proteases in inflammation).

Binette, J. P., and Schmid, K. (1965). Arthr. and Rheum., 8, 14 (The proteins of synovial fluid: A study of the $a_{1} \alpha_{2}$ globulin ratio).

Bluhm, G. B., Riddle, J. M., and Barnhart, M. I. (1966). Henry Ford Hosp. med. Bull., 14, 119 (Significance of fibrin and other particulates in rheumatoid joint inflammation).

Bole, G. G. (1962). Arthr. and Rheum., 5, 589 (Synovial fluid lipids in normal individuals and patients with rheumatoid arthritis).

Cho, M. H., and Neuhaus, O. W. (1960). Thrombos. Diathes. haemorrh. (Stuttg.), 5, 108 (Absence of blood clotting substances from synovial fluids).

Decker, B., McKenzie, B. F., McGuckin, W. F., and Slocumb, C. H. (1959). Arthr. and Rheum., 2, 162 (Comparative distribution of proteins and glycoproteins of serum and synovial fluid).

Glynn, L. E. (1963). Bull. rheum. Dis., 14, 323 (Symposium on inflammation and role of fibrin in the rheumatic diseases).

Guest, M. M. (1954). J. clin. Invest., 33, 1553 (Profibrinolysin, antifibrinolysin, fibrinogen and urine fibrinolytic factors in the human subject).

Hollander, J. L., McCarty, D. J., Jr., Astorga, G., and Castro-Murillo, E. (1965). Ann. intern. Med., 62, 271 (Studies on the pathogenesis of rheumatoid joint inflammation. I. The "R.A. cell" and a working hypothesis).

Jacox, R. F., and Feldmahn, A. (1955). J. clin. Invest., 34, 263 (Variations of beta glucuronidase concentration in abnormal human synovial fluid).

Kellermeyer, R. W., and Breckenridge, R. T. (1966). J. Lab. clin. Med., 67, 455 (The inflammatory process in acute gouty arthritis. II. The presence of Hageman factor and plasma thromboplastin antecedent in synovial fluid).

Kling, D. H. (1938). "The Synovial Membrane and the Synovial Fluid." Medical Press, Los Angeles, California.

Krehl, W. A., Boisvert, P. L., de Forest, G. K., and Mucci, M. B. (1957). Yale J. Biol. Med., 30, 30 (The Rheumatoid factor in serum and synovial fluid).

Lewis, J. H., Szeto, I. L. F., Martinez, R. C., Bayer, W. L., Spero, J. A., and Rodnan, G. P. (1966). Arthr. and Rheum., 9, 520 (Abstract: Coagulation factors and intracellular fibrin in synovial fluid).

Nussenzweig, V., and Seligmann, M. (1960). Rev. Hémat., 15, 451 (Analyse, par des méthodes immunochimiques, de la dégradation par la plasmine du fibrinogène humain et de la fibrine, à différents stades).

Purcell, G. M., and Barnhart, M. I. (1963). Biochim. biophys. Acta, 78, 800 (Prothrombin activation with cathepsin C).

Riddle, J. M., and Barnhart, M. I. (1964). Amer. J.Path., 45, 805 (Ultrastructural study of fibrin dissolution via emigrated polymorphonuclear neutrophils).

—_ (1965). Blood, 25, 776 (The eosinophil as a source for profibrinolysin in acute inflammation.)

—, Bluhm, G. B., and Barnhart, M. I. (1965). J. reticuloendoth. Soc., 2, 420 (Interrelationships between fibrin, neutrophils and rheumatoid synovitis).

,,--- , and Odle, N. A. (1966). Unpublished observations.

Robinson, H. W., and Hogden, C. G. (1940). J. biol. Chem., 135, 707 (The biuret reaction in the determination of serum proteins).

Ropes, M. W., and Bauer, W. (1953). "Synovial Fluid Changes in Joint Disease". Harvard University Press, Cambridge, Mass. 
Rose, H. M., Ragan, C., Pearce, E., and Lipman, M. O. (1948). Proc. Soc. exp. Biol. (N. Y.), 68, 1 (Differential agglutination of normal and sensitized sheep erythrocytes by sera of patients with rheumatoid arthritis).

Schmid, K. (1964). In "Immuno-electrophoretic Analysis", ed. P. Grabar and P. Burtin, p. 256. Elsevier, Amsterdam, London, and New York.

Schur, P. H., and Sandson, J. (1963). Arthr. and Rheum., 6, 115 (Immunologic studies of the proteins of human synovial fluid).

Seegers, W. H. (1962). “Prothrombin”. Harvard University Press, Cambridge, Mass.

- Miller, K. D., Andrews, E. B., and Murphy, R. C. (1952). Amer. J. Physiol., 169, 700 (Fundamental interactions and effect of storage, ether, adsorbants and blood clotting on plasma antithrombin activity).

—, Nieft, M. L., and Vandenbelt, J. M. (1945). Arch. Biochem., 7, 15 (Decomposition products of fibrinogen and fibrin).

Smith, C., and Hamerman, D. (1962). Arthr. and Rheum., 5, 411 (Acid phosphatase in human synovial fluid).

Stirland, R. M. (1956). Lancet, 1, 672 (A rapid method of estimating fibrinogen).

Takeda, Y., and Reeve, E. B. (1965). Fed. Proc., 24, 386 (Abstract : Fibrinogen metabolism in patients with rheumatoid arthritis).

Ware, A. G., and Seegers, W. H. (1949). Amer. J. clin. Path., 19, 471 (Two-stage procedure for the quantitative determination of prothrombin concentration).

—- Guest, M. M., and Seegers, W. H. (1947). Arch. Biochem., 13, 231 (Fibrinogen: With special reference to its preparation and certain properties of the product).

Ziff, M., Simson, J., Scull, E., Smith, A., Shatton, J., and Mainland, D. (1955). J. clin. Invest., 34, 27 (Aminotripeptidase content of synovial fluid in arthritic diseases).

Zweifach, B. W., Grant, L., and McCluskey, R. T. (1965). "The Inflammatory Process”. Academic Press, New York.

Fibrinosynthèse et fibrinolyse dans l'arthrite rhumatismale

\section{RÉSUMÉ}

On étudia la biochimie des protéines de 144 liquides synoviaux, représentant plusieurs types de maladie articulaire, avec attention particulière sur les protéines qui favorisent la formation ou la lyse de la fibrine. On trouva dans les liquides synoviaux la prothrombine, le fibrinogène, l'antithrombine III, la profibrinolysine et des produits de dégradation de la fibrine. Les quantités de ces protéines y furent variables. Nous croyons à présent que ces différences quantitatives correspondent à de différents degrés d'inflammation plutôt qu'à une biochimie particulière des types de la maladie articulaire. La formation des dépôts irrésolubles de fibrine peut endommager l'articulation d'une façon permanente. Un mécanisme pour enlever la fibrine de bonheur et d'une manière efficace pourrait accélérer le cours de la guérison.
Fibrinosintesis y fibrinolisis en la artritis reumatoid

\section{SUMARIO}

Se estudió la bioquímica de las proteinas de 144 líquidos sinoviales, representando varios tipos de enfermedad articular, con atención particular a aquellas proteinas que fomentan la formación y la lisis de la fibrina. Encontràronse en estos líquidos protrombina, fibrinógeno, antitrombina III, profibrinolisina y productos de degradación de la fibrina. En estos exudados inflamatorios la cuantidades de tales proteinas fueron variables. Nuestra interpretación actual es que estas diferencias cuantitativas reflejan diferentes grados de inflamación más bien que una bioquímica particular de los tipos de la enfermedad articular. La formación continua de depósitos de fibrina sin resolverse puede dañar la articulación permanentemente. Un mecanismo para eliminar la fibrina rapida y eficazmente podría acelerar el proceso recuperativo. 